\title{
Acute Impact of Herbicide Strip Treatment on Mixed-Brush White-tailed Deer Habitat on the Northern Rio Grande Plain
}

\section{G. W. TANNER, J. M. INGLIS, AND L. H. BLANKENSHIP}

Highlight: White-tailed deer tended to evacuate a 1,800-ha, mixed-brush pasture during 5 months following aerial stripspraying in May with 2,4,5-T + picloram (1:1) at $0.56 \mathrm{~kg} / \mathrm{ha}$ and $1.12 \mathrm{~kg} / \mathrm{ha}$ and in two widths $(80 \%$ coverage $)$. Deer were attracted to the pasture in above-normal numbers the following winter but their numbers returned to normal by 11 months posttreatment. Apparently, succulent woody plant regrowth provided an attractive food base which induced the posttreatment increase in numbers. Deer on the pasture did not rearrange their use to favor untreated brush as a response to treatment rate or width of treated strip. Woody plant canopy cover was significantly reduced on all treated strips but cover screen at deer height was unaffected. Evidence suggests that only the high rate of herbicide application resulted in significant reduction in the stature of brush. Density of live brush stems was reduced less than $20 \%$ by treatment.

\footnotetext{
The authors are, respectively, research assistant and professor, Wildlife and Fisheries Sciences. Texas A\&M Univ.. College Station: and professor. Texas A\&M Univ. Agriculture Research and Extension Center at Uvalde.

This report is published with approval of the Director, Iexas Agr. Exp. Sta. as TA-13753.

The authors wish to express their indebted ness to B. K. Johnson, owner Chaparrosa Ranch for providing partial financial assistance and land; Ceasar Kleberg Research Program in Wildlife Ecology at Texas A\&M University and Texas Agricultural Experiment Station at College Station (Project 1203) for financial support, and the Texas Agricultural Experiment Station at Uvalde for logistic support. This is contribution TA. 13753, Texas Agri. Exp. Sta.

Special thanks are extended to R. B. Shaw, research assistant, and Dr. Jimmy D. Dodd, professor, Dep. Range Sci., Texas A\&M Univ., for the use of woody plant data.

Manuscript received October 21,1977
}

Since the arrival of European man on the Rio Grande Plain, the physiognomy of vegetation has changed drastically. The modification has been from an open, extensive prairie with few scattered shrubs on the upland and a tendency toward chaparral along drainages and rocky outcrops (Inglis 1964) to what recently has been described as "thorn scrub" (Muller 1974). The overall increase of woody plant density and coverage has significantly reduced livestock carrying capacity.

The Rio Grande Plain is noted for its trophy whitetailed deer (Odocoileus virginianus). Woody plant cover has long been accepted as one of the habitat attributes which makes the "brush country" such a good deer range. Also, the sale of hunting rights affords important economic returns to ranch operators (Teer and Forrest 1968; Whitson et al. 1977). Therefore, compromises between clearing woody plants for livestock operations and leaving cover for deer seem appropriate.

A recent development in brush management has been the use of phenoxy herbicides, such as 2,4,5-T ( (2,4,5-trichlorophenoxy) acetic acid) in combination with picloram (4-amino-3,5,6-tricholoropicolinic acid). To evaluate the impact of these chemicals on deer habitat, and to provide information which might form the basis for management compromises, a joint research effort between range and 
wildlife researchers of the Texas Agricultural Experiment Station was designed to evaluate the impact of strip treatments on woody and herbaceous plants and on patterns of deer use. The paper describes some acute impacts of herbicide treatment on habitat attributes and the dynamics of deer response to treatment. Field work was conducted from April 1973 until December 1974.

\section{Study Area}

The study was conducted on the Chaparrosa Ranch, Zavala County, Texas in the northwestern portion of the Rio Grande Plain. Average annual precipitation at the ranch headquarters has been $55.3 \mathrm{~cm}$ during the past 14 years.

An 1,800-ha pasture located on a broad ridge with low rolling terrain was selected for intensive study. Shallow drainages exited the pasture to the south, west, east, and northeast. According to the Davis and Spicer (1965) classification of dominant vegetation types on the Rio Grande Plain, the pasture is on the transition between Deep Loams and Clays-Mesquite brush types. Although the woody vegetation was physiognomically homogeneous throughout the pasture, six vegetation types were delineated based on ocular estimates of dominant woody plant species. These were (1) Whitebrush (Aloysia lycioides) Drain:(2) Mesquite (Prosopis glandulosa var. glandulosa); (3) Mixed Whitebrush, a mixture of whitebrush and mesquite located on clay loam flats; (4) Mixed Brush, codominants of mesquite, blackbrush acacia (Acacia rigidula), and twisted acacia (Acacia tortuosa); (5) Blackbrush acacia, located on ridge tips; and (6) Pricklypear (Opuntia lindheimeri).

The pasture was continuously grazed with occasional 45- to 60-day deferments. During the study, cattle stocking rate on the pasture increased from 10.1 ha per A. U. in October 1973 to 7.3 ha per A.U. in December 1974.

\section{Materials and Methods}

The study pasture was strip sprayed with a commercial formulation of 2,3,5-T plus picloram (1:1) in May 1973. On the east half of the study pasture, the chemical was applied at $1.12 \mathrm{~kg} /$ ha a.e. (high rate) in narrow strips which averaged $476 \mathrm{~m}$ wide (Fig. 1). The west half of the pasture received $0.56 \mathrm{~kg} /$ ha a.e. (low rate) in strips which averaged $1,027 \mathrm{~m}$ wide. Untreated strips on the eastern and western halves of the pasture averaged $165 \mathrm{~m}$ and $252 \mathrm{~m}$ wide, respectively. Overall, approximately $80 \%$ of the pasture was treated.

Two pairs of strips were selected for sampling vegetation and deer use: adjacent, high rate treated and untreated narrow strips and, low rate treated and untreated wide strips (Fig. 1). Along the center of cach sample strip, 25 circular vegetation plots were marked at $200-\mathrm{m}$ intervals by a metal rod driven into the ground. Each rod represented the center of a 0.004 -ha vegetation sampling plot (radius $=3.95 \mathrm{~m})$. Within a maximum transverse and longitudinal distance of $80 \mathrm{~m}$ of each of the 100 vegetation plots, three more permanent 0.004 -ha circular plots were randomly located on a grid pattern using the metal rod as a point of origin. These were used to measure the rate and distribution of deer pellet group deposition.

Woody plant canopy cover was measured directly from preand posttreatment aerial infrared photographs of the pasture $(R F=1: 8,000)$. Measurements were made on the film in the vicinity of each vegetation plot using a random-dot grid. Percent canopy cover was estimated by counting the numbers of dots striking living woody plants canopy (above grass height).

Woody plant cover screening was estimated using a visibility board (Wight 1938). The board was $1.8 \mathrm{~m}$ tall by $15.2 \mathrm{~cm}$ wide with sequential $0.3-\mathrm{m}$ segments painted alternately black and white. In the center of each segment, $15.2 \mathrm{~cm}$-high numerals 1 through 6 were placed in increasing order, bottom to top. To estimate the amount of screen produced by woody plants and the rate of screen
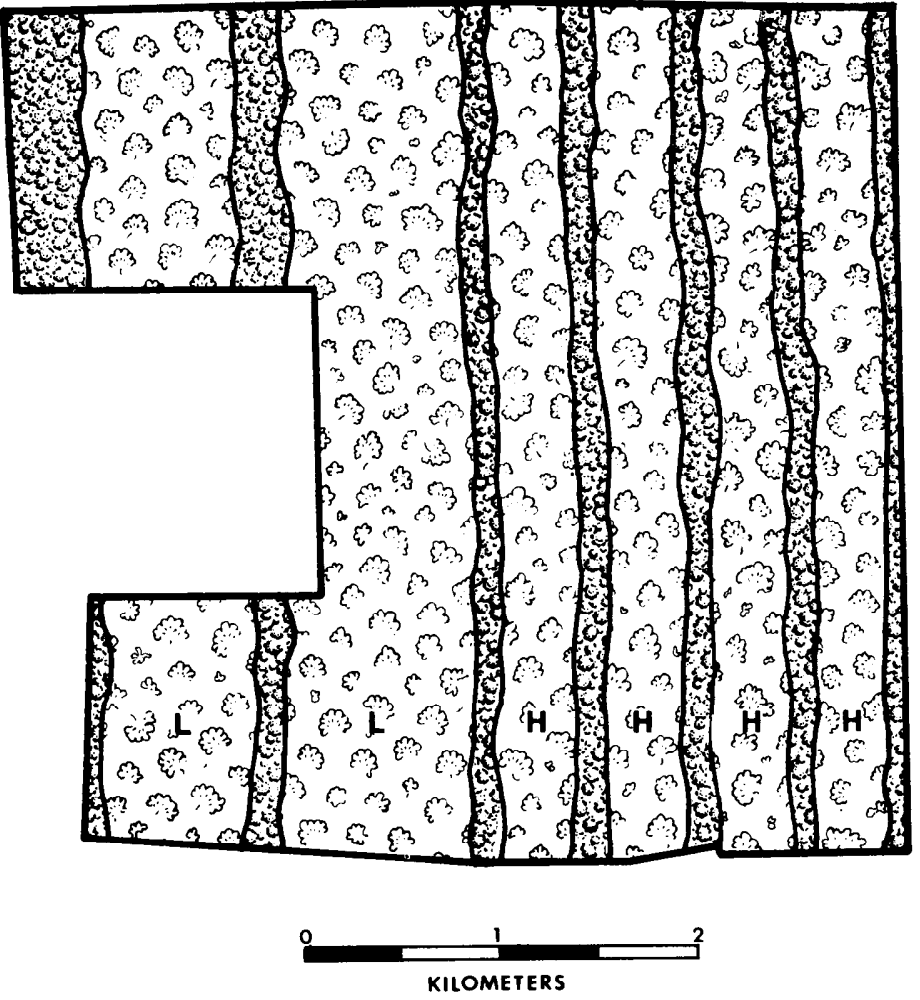

Fig. 1. Pattern of treatment strips where vegetative and white-tailed deer responses to aerial application of $2,4,5-T+$ picloram on South Texas Plain mixed brush at two rates, low $(L)=0.56 \mathrm{~kg} / \mathrm{ha}$ and high $(H)=$ $1.12 \mathrm{~kg} / \mathrm{ha}$ nere evaluated.

closure, readings were taken at 15.2 and $30.5 \mathrm{~m}$ distances in the east and west directions at each vegetation plot.

The observer knelt to approximate the height of a deer's eye while taking readings, and only visible numerals were recorded. Those numerals screened at the 0.3, 0.6, and $0.9 \mathrm{~m}$-height levels pertained to the cover screen up to deer height. At each vegetation plot the sum of the total number of numerals, tallied in both the east and west directions, provided an index of cover screen ranging from 0 (no screening) to 6 (total screening) at the two observation distances. The mean of thesc indices around vegetation plots within different brush strata provided screening indices. Readings at $1.2,1.5$, and $1.8 \mathrm{~m}$ heights were handled similarly to provide an index for "high screen."

Estimated distances at which total screen closure would occur at deer height and high screen levels were estimated by linear extrapolation of mean screening index values per stratum read at the 15.2 $m(x)$ and $30.5 m(v)$ observation distances to $100 \%$ screening using the following formula:

\section{$\begin{aligned} & \text { Estimated Average } \\ & \text { Closure Distance }\end{aligned}=\left[\left(\frac{6.0-x}{y-x}\right) \times 15.2 m\right]+15.2 m$}

Immediately prior to herbicide treatment, plants and stems of all woody plant species were counted on the vegetation plots. A subsequent count after initiation of spring growth was made 1 year posttreatment. During posttreatment readings, plants and stems were classified as being more or less than $1.5 \mathrm{~m}$ tall to evaluate browse availability.

Belt transects were used to estimate forb density, species composition, and standing crop biomass in mid-spring and early fall 1974,11 and 15 months posttreatment, respectively. Two transect samples, $3 \mathrm{~m}$ long by $15.2 \mathrm{~cm}$ wide and extending from the metal center stake of vegetation plots, were taken near each permanent sampling point. Direction of transect placement was 
determined by spinning a wooden arrow on top of the center stake. Forbs encountered within each transect were counted and clipped at ground level by species, oven-dried for $30 \mathrm{~h}$ at $80^{\circ} \mathrm{C}$, and weighed.

The 300 pellet group plots were cleared of existing pellet groups in April 1973, and were checked and cleared at monthly intervals through November 1974. Counts for June and September 1973 were not taken due to rain. Also, the annual hunting season precluded counts in December 1973 and 1974. A pellet group was defined to consist of six or more pellets, and was counted if any individual pellet fell within the $3.59 \mathrm{~m}$ radius of the plot. Raw pellet group data were assumed to fit the negative binomial distribution (McMahan 1973). The inverse hyperbolic sine was used to transform raw pellet group data for anlayses.

Deer censuses were made from fixed wing aircraft or helicopter in January, May, and October, 1973, and November, 1974. Monthly pellet group counts were also used to establish population trends during the study (Robinette et al. 1958).

\section{Results and Discussion}

\section{Woody Plant Canopy Cover}

Woody plant canopy cover was equated with shade for deer. Herbicide application significantly reduced $(P<0.01)$ the canopy from 22 and $27 \%$ before treatment on the strips receiving the high and low rates, respectively, to 5 and $7 \% 1$ year posttreatment. Canopy reduction did not imply plant mortality. Many plants had "flags" indicating partial crown survival. No significant difference occurred between the percent canopy cover on the untreated eastern and western halves of the pasture, either before or after treatment. The residual canopy cover in treated areas consisted of flags and woody plants that were not defoliated by the spray, e.g., Texas persimmon (Diospyros texana), guayacan (Porlieria angustifolia), bluewood (Condalia obovata), and whitebrush.

The whitebrush drain vegetation type had substantially greater canopy cover than all other vegetation types prior to and 1 year following herbicide treatment (Table 1). All vegetation types except whitebrush drain were 75 to $94 \%$ defoliated. Whitebrush was not significantly affected by the herbicide, but canopy cover for the untreated mixed white-

Table 1. Mean woody plant canopy cover (\%) of vegetation types prior to treatment with 2,4,5-T + picloram (1:1) and after 1 year on the South Texas Plain near LaPryor in 1973.

\begin{tabular}{lccc}
\hline & \multicolumn{3}{c}{ Mean Canopy Cover $(\%)^{1,2}$} \\
\cline { 2 - 4 } Vegetation type & $\begin{array}{c}\text { Pretreatment } \\
\text { overall }\end{array}$ & $\begin{array}{c}\text { Posttreatment } \\
\text { unsprayed }\end{array}$ & $\begin{array}{c}\text { Posttreatment } \\
\text { sprayed }\end{array}$ \\
\hline Whitebrush drain & $45.0 \mathrm{~b}$ & $32.9 \mathrm{a}$ & $37.0 \mathrm{~b}$ \\
Blackbrush & $21.9 \mathrm{a}$ & $17.4 \mathrm{ab}$ & $5.6 \mathrm{a}$ \\
Mixed whitebrush & $20.2 \mathrm{a}$ & $15.1 \mathrm{~b}$ & $4.9 \mathrm{a}$ \\
Mixed brush & $23.3 \mathrm{a}$ & $29.3 \mathrm{ab}$ & $4.5 \mathrm{a}$ \\
Mesquite & $29.0 \mathrm{a}$ & $21.2 \mathrm{ab}$ & $4.3 \mathrm{a}$ \\
Pricklypear & $16.3 \mathrm{a}$ & $25.5 \mathrm{ab}$ & $1.0 \mathrm{a}$ \\
\hline
\end{tabular}

Canopy cover of vegetation types on unsprayed strips 1 year following treatment are included for comparison with pretreatment overall conditions.

2 Within each treatment, those values followed by the same letter are not significantly different at the 0.05 level according to Duncan's multiple range test.

brush type was reduced $29 \%$ due to defoliation of species other than whitebrush by spray drift.

\section{Vegetative Screen}

Herbicide treatment did not affect $(P>0.05)$ the esti- mated average closure distance (EACD) of deer-height woody cover (Table 2). Distance to closure increased significantly in the high screen. Screen at lower levels was produced by ground layer vegetation unaffected by treatment, basal sprouts, and persistent stems of the defoliated woody plants. Reduction in high screen resulted mainly from crown defoliation; all but the smallest woody twigs persisted after treatment.

Table 2. Average screening indices on untreated and high rate, and untreated and low rate strips at deer height and high screen, measured at 15.2 and $30.5 \mathrm{~m}$ after application of 2,4,5-T + picloram (1:1) on the South Texas Plain near LaPryor in 1973.

\begin{tabular}{|c|c|c|c|c|c|}
\hline \multirow{2}{*}{ Screen level } & \multirow{2}{*}{$\begin{array}{c}\text { Herbicide } \\
\text { rate }^{1}\end{array}$} & \multirow{2}{*}{ Treatment } & \multicolumn{2}{|c|}{$\begin{array}{l}\text { Screening indices at } \\
\text { observation distances }^{2}\end{array}$} & \multirow{2}{*}{$\begin{array}{c}\text { Closure } \\
\text { distance } \\
\text { EACD }(m)^{3}\end{array}$} \\
\hline & & & $15.2 \mathrm{~m}$ & $30.5 \mathrm{~m}$ & \\
\hline Deer height & High & $\begin{array}{l}\text { Untreated } \\
\text { Treated } \\
\text { Untreated } \\
\text { Treated }\end{array}$ & $\begin{array}{l}3.7 \mathrm{a} \\
2.7 \mathrm{a} \\
3.7 \mathrm{a} \\
4.0 \mathrm{~b}\end{array}$ & $\begin{array}{l}4.7 \mathrm{a} \\
4.3 \mathrm{~b} \\
4.9 \mathrm{a} \\
5.0 \mathrm{a}\end{array}$ & $\begin{array}{l}48 \\
47 \\
45 \\
46\end{array}$ \\
\hline High screen & High & $\begin{array}{l}\text { Untreated } \\
\text { Treated } \\
\text { Untreated } \\
\text { Treated }\end{array}$ & $\begin{array}{l}1.9 \mathrm{~b} \\
0.9 \mathrm{a} \\
2.3 \mathrm{c} \\
1.7 \mathrm{~b}\end{array}$ & $\begin{array}{l}3.4 \quad b \\
1.9 \mathrm{a} \\
3.9 \mathrm{c} \\
3.1 \mathrm{~b}\end{array}$ & $\begin{array}{l}57 \\
92 \\
51 \\
62\end{array}$ \\
\hline
\end{tabular}

I The low rate was $0.56 \mathrm{~kg} / \mathrm{ha}$ and the high rate was $1.12 \mathrm{~kg} / \mathrm{ha}$ applied in May 1973 ${ }^{2}$ Screening indices within separate observation distance-screen level combinations followed by the same letter are not significantly different at the 0.05 level according to Duncan's range test.

${ }^{3}$ Estimated average closure distances (EACD) were obtained by straight line extrapolation. Screening indices are averages from measurements taken in February, late March, and October, 1970, 10, 11, and 18 months posttreatment, respectively.

\section{Woody Plants as Browse}

The extent of loss of canopy cover indicates the acute effect of the availability of browse on the treated ground. In the weeks immediately following treatment, the aspect of the treated shrubby vegetation changed from luxuriant green to stark gray and there was little sign of life in those species of shrubs most damaged by treatment. However, within 6 months, residual living stems and plants developed leaves and basal and root sprouts, and regrowth began.

Herbicide treatment appreciably reduced the number of living shrubs and stems (Table 3) but important browse species responded differentially to the treatments in terms of the number of browse-bearing stems available (Table 4). Number of living stems increased during the study on the untreated strips. The effect of treatment was that desert yaupon (Schaefferia cuneifolia) increased less, and the herbicide absolutely reduced numbers of living stems of

Table 3. Net change in the number of living shrubs and stems (/ha) on untreated sample plots and plots receiving two rates of $2,4,5-\mathrm{T}+$ picloram (1:1) between 1973 (pretreatment) and 1974 (posttreatment) on the South Texas Plain near LaPryor. (Data modified from Shaw 1976).

\begin{tabular}{lcrcc}
\hline \hline Attributc & $\begin{array}{c}\text { Herbicide } \\
\text { ratel }\end{array}$ & Pretreatment & Posttreatment & $\begin{array}{c}\text { Difference } \\
(\%)\end{array}$ \\
\hline Shrubs/ha & & 5,322 & 5,179 & -2.7 \\
Stems/ha & & 33,955 & 36,838 & +8.5 \\
Shrubs/ha & Low & 7,364 & 6,137 & -16.7 \\
Stems/ha & Low & 36,047 & 29,148 & -19.1 \\
Shrubs/ha & High & 3,905 & 3,173 & -18.7 \\
Stems/ha & High & 17,158 & 13,640 & -20.5 \\
\hline
\end{tabular}

I Low rate was $0.56 \mathrm{~kg} / \mathrm{ha}$ and high rate was $1.12 \mathrm{~kg} / \mathrm{ha}$. 
Table 4. Net change (\%) in the stems/ha of certain important species of shrubs on untreated sample plots and plots receiving two rates of 2,4,5-T + picloram (1:1) between 1973 (pretreatment) and 1974 (posttreatment) on the South Texas Plain near LaPryor. (Data modified from Shaw 1976).

\begin{tabular}{lccc}
\hline \multirow{2}{*}{ Species } & Untreated & \multicolumn{2}{c}{ Herbicide rate } \\
\cline { 3 - 4 } & & Low & High \\
\hline Desert yaupon & +64.4 & +58.2 & +24.1 \\
Spiny hackberry & +21.3 & -15.4 & -33.3 \\
Blackbrush & +20.5 & -3.9 & -42.5 \\
Twisted acacia & +16.2 & -30.1 & -68.1 \\
Pricklypear & +72.5 & $-100.0^{2}$ & -55.6 \\
\hline
\end{tabular}

' Low rate was $0.56 \mathrm{~kg} / \mathrm{ha}$ and high rate was $1.12 \mathrm{~kg} / \mathrm{ha}$.

${ }^{2} \mathrm{Few}$ plants occurred on sample plots.

spiny hackberry (Celtis pallida), blackbrush acacia, and twisted acacia. Control of these species was roughly a function of herbicide rate. Pricklypear abundance was greatly reduced by both intensities of treatment.

The negative herbicide effect on browse availability should be offset somewhat because the stature of the brush was reduced (Box and Powell 1965), making more browse available to deer on the treated strips. This latter assumption was borne out since a greater percentage of the residual brush on the strips receiving the high rate of treatment was within reach of deer if $1.5 \mathrm{~m}$ approximates the height to which they will reach to feed (Table 5). Taller stems partially survived (flagged) in the lower intensity treatment and a higher proportion of the residual browse remained out of the deer's reach.

Table 5. Percentage of living stems falling in different classes relative to their availability as browse 1 year after application of $2,4,5-T+$ picloram (1:1) on the South Texas Plain near LaPryor.

\begin{tabular}{lcccc}
\hline \hline \multirow{2}{*}{$\begin{array}{c}\text { Browse } \\
\text { availability } \\
\text { to deer }\end{array}$} & Height & Untreated & \multicolumn{2}{c}{ Herbicide ratel } \\
\cline { 4 - 5 } & $>1.5 \mathrm{~m}$ & 6.6 & 3.9 & 0.3 \\
$\begin{array}{l}\text { Partially } \\
\text { inaccessible }\end{array}$ & Flagged ${ }^{2}$ & 0.7 & 4.0 & 1.5 \\
$\begin{array}{l}\text { Completely } \\
\text { accessiblc }\end{array}$ & $<1.5 \mathrm{~m}$ & 74.0 & 60.1 & 74.6 \\
$\begin{array}{c}\text { \% Completely } \\
\text { accessible }\end{array}$ & Basal Sprouts & 18.7 & 32.0 & 23.6 \\
\hline
\end{tabular}

' Low rate was $0.56 \mathrm{~kg} / \mathrm{ha}$ and high rate was $1.12 \mathrm{~kg} / \mathrm{ha}$ applied in May 1973. ${ }^{2}$ Stem $1.5 \mathrm{~m}$ tall with evidence of partial top kill.

Forbs

Close inspection showed that this important class of deer forage (Drawe 1968; Chamrad and Box 1968; Everitt and Drawe 1974; Darr and Klebenow 1975; Beasom and Scifres 1977) was decimated on treated areas immediately after treatment. However spraying occurred in a dry period, and the contrast in forb abundance between treated and untreated areas was not great. Heavy rains beginning a month posttreatment initiated favorable forb growth over the entire pasture. Thereafter, the forbs were abundant through the following winter.

Between-treatment differences in forb biomass at 11 and 15 months posttreatment revealed less biomass in treated vs untreated plots in three out of four cases (Table 6).
Table 6. Average forb standing crop biomass (oven dry $30 \mathrm{~h}$ at $80 \mathrm{C}$ ) on four sample strips measured Spring and Fall 1974, 11 and 15 months after application of 2,4,5-T + picloram (1:1) on the South Texas Plain near LaPryor.

\begin{tabular}{clcc}
\hline \hline $\begin{array}{c}\text { Herbicide } \\
\text { ratel }\end{array}$ & Treatment & $\begin{array}{c}\text { Forb standing crop biomass } \\
(\mathrm{kg} / \mathrm{ha})\end{array}$ \\
\hline & & Spring & Fall \\
\cline { 3 - 3 } High & Untreated & 46.6 & 128.9 \\
& Treated & 83.2 & 94.5 \\
Low & Untreated & 104.9 & 77.8 \\
& Treated & 60.5 & 56.4 \\
\hline
\end{tabular}

1 Low rate was $0.56 \mathrm{~kg} / \mathrm{ha}$ and high rate was $1.12 \mathrm{~kg} / \mathrm{ha}$ applied in May 1973.

However, the variance within treatments was so great that differences were not significant.

\section{Deer Reponses}

We felt that two types of responses to the patterned herbicide treatment were possible. First, deer could perceive the treatment as a pasture-wide event. Negative response to a "treated pasture" would then result in deer shifting their use out of the pasture. This was evaluated by means of pasture-wide aerial censuses. Secondly, deer could rearrange their activity within the pasture to make use of the new habitat mosaic provided by untreated and treated strips. Comparative rates of pellet group deposition on treated and untreated plots were used to evaluate this response.

As estimated from an aerial census 3 months following herbicide application, numbers of deer on the pasture greatly declined following the May 5 treatment. They declined from an estimated 312 animals in January 1973, to 51 animals the following August (Fig. 2). By October, some

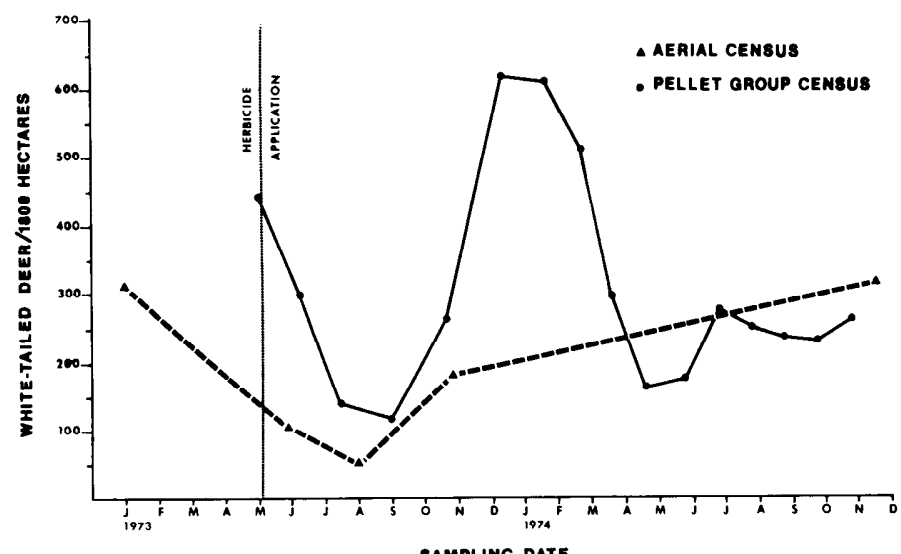

Fig. 2. Trends in deer numbers, estimated from aerial and pellet group censuses, as associated with herbicide treatment applied May 5, 1973.

deer had returned to the pasture since 183 were counted during a helicopter survey. Numbers of deer in the pasture in November, 1974, approximated those before treatment.

Since pellet groups were counted monthly they showed more detail than aerial censuses for trends in deer number. The same basic trends shown by aerial censuses were indicated. A downward trend in deer numbers declined from initiation of sampling to an August low, then both census methods showed a parallel increase until late October. Pellet 
Table 7. Seasonal average pellet groups/plot/day $\left(\mathrm{n} \times 10^{-3}\right)$ on four sample strips after application of $2,4,5-\mathrm{T}+$ picloram $(1: 1)$ on the South Texas Plain near La Pryor in May 1973.

\begin{tabular}{|c|c|c|c|c|c|c|c|}
\hline \multirow{2}{*}{$\begin{array}{c}\text { Herbicide } \\
\text { ratel }\end{array}$} & \multirow{2}{*}{ Treatment } & \multicolumn{6}{|c|}{ Season } \\
\hline & & Summer '73 & Fall '73 & Winter '73-74 & Spring $74^{2}$ & Summer 74 & Fall ' 74 \\
\hline \multirow{2}{*}{ High } & Untreated & 8 & 3 & 13 & 6 & 5 & 7 \\
\hline & Treated & 12 & 7 & 25 & 10 & 5 & 7 \\
\hline \multirow{2}{*}{ Low } & Untreated & 5 & 5 & 16 & 4 & 12 & 8 \\
\hline & Treated & 3 & 6 & 10 & 5 & 8 & 7 \\
\hline
\end{tabular}

'Low rate was $0.56 \mathrm{~kg} / \mathrm{ha}$ and high rate was $1.12 \mathrm{~kg} / \mathrm{ha}$.

2 Values followed by the same letter are not significantly different at the 0.05 level according to Duncan's multiple range test.

group data show that this increase in deer numbers continued until late December, then numbers declined and had stabilized by April, 1974. Subsequent studies show that the population was relatively stable at around 225 to 300 deer in the pasture until, at least, November, 1976 (Ralph N. Marshall and Ross S. McKenny, Unpub. ms.). Thus, it appears that the deer responded to the strip treatments as a pasture-wide phenomenon. These responses parallel those reported by Beasom and Scifres (1977), especially on their broadcast sprayed area.

The highs in deer numbers shown by the pellet group data in May 1973 and January 1974, are unrealistic. In May this was to be expected, since it takes time for personnel to get previously untended pellet group plots cleared of residual pellet groups. The second peak is harder to explain. A peak occurred, but it is highly unlikely that the actual population was 600 animals. The peak occurred synchronously with a winter flush in forbs and succulent new browse produced on the treated areas as shrubs attempted to reestablish a photosynthetic base. The defecation rate of deer is reported to increase when animals are feeding on succulent new growth (Longhurst 1954; Dasmann and Taber 1955; McMahan 1973), but this could not account for such large estimated numbers. "New" deer must have been attracted to the pasture.

The deer did not rearrange their internal use of the pasture to favor untreated brush as a response to treatment rate or width of treated strip according to the pellet group data (Table 7). A significant difference in the rate of pellet-group accumulation within any stratum occurred only in Spring, 1974, when the mean rate was significantly higher in the narrow strip that received the high rate of herbicide.

Further analysis showed no significant difference in the rate of pellet-group accumulation between treated and untreated stands of the different brush types within seasons (Table 8). Also, differences between the rate of pellet-group accumulation within the 12 strata were not significant except in Fall, 1973. In that instance, untrcated mixed whitebrush ranked higher than treated whitebrush drain, but neither of these types accumulated deer pellets at a rate that was significantly different from the remainder of the types. The lowest rate of pellet group accumulation in all seasons was in whitebrush drains. Since whitebrush was unaffected by treatment this result has few implications relative to treatment effects.

\section{Conclusions}

For an area to be habitable for deer it must provide cover (shade and screen), food, and water (Severinghaus and Cheatum 1956). Our results indicated that chemical treatment of brush caused, (1) a $75 \%$ to $80 \%$ reduction in woody plant crown cover, (2) a major acute but minor chronic reduction in brush stems supporting browse, (3) an observed acute reduction in forb availability for 2 months immediately following herbicide application on the treated strips. Browse reduction from the higher herbicide rate was partially offset by increased accessibility and the quality improvement associated with new growth. Screening cover was unaffected by treatment.

The deer response involved a year-long perturbation in numbers in the pasture that was synchronized with the more dynamic aspects of the vegetative response to treatment. The response was to conditions as they changed in the pasture as a whole. At no time was there any indication that the deer in the pasture responded differentially to treated and untreated strips, or their width, or to woody plant vegetation types within them either during or after the perturbation in pasture-wide numbers.

Both aerial and pellet group censuses indicated that some animals shifted their home ranges outward across the pasture fences during the period when browse and forb food supplied were much reduced because of treatment. Appar-

Table 8. Seasonal average pellet groups/plot/day $\left(\mathrm{n} \times 10^{3}\right)$ within untreated $(\mathrm{U})$ and treated $(\mathrm{T})$ vegetation types following application of $2,4,5-\mathrm{T}+$ picloram (1:1) on the South Texas Plain near La Pryor in May 1973.

\begin{tabular}{|c|c|c|c|c|c|c|c|c|c|c|c|c|}
\hline & \multicolumn{2}{|c|}{ Summer 1973} & \multicolumn{2}{|c|}{ Fall 1973' } & \multicolumn{2}{|c|}{ Winter-1973-74 } & \multicolumn{2}{|c|}{ Spring 1974} & \multicolumn{2}{|c|}{ Summer 1974} & \multicolumn{2}{|c|}{ Fall 1974} \\
\hline & U & $\mathrm{T}^{2}$ & $\mathrm{U}$ & $\mathrm{T}^{2}$ & $\mathrm{U}$ & $\mathrm{T}^{2}$ & $\mathrm{U}$ & $\mathrm{T}^{2}$ & $\mathrm{U}$ & $\mathrm{T}^{2}$ & $\mathrm{U}$ & $\mathrm{T}^{2}$ \\
\hline Whitebrush drain & 0 & 0 & 1 & 3 & 6 & 6 & 3 & 0 & 0 & 2 & 2 & 0 \\
\hline Mesquite & 5 & 18 & 3 & 8 & 24 & 11 & 9 & 9 & 12 & 8 & 6 & 6 \\
\hline Mixed whitebrush & 16 & 11 & 4 & 1 & 16 & 18 & 7 & 6 & 7 & 6 & 14 & 8 \\
\hline Mixed brush & 9 & 3 & 5 & 6 & 14 & 16 & 3 & 6 & 11 & 8 & 8 & 6 \\
\hline Blackberry & 4 & 3 & 7 & 4 & 19 & 18 & 9 & 12 & 4 & 5 & 12 & 7 \\
\hline Pricklypear & 3 & 9 & 4 & 4 & 3 & 46 & 2 & 13 & 11 & 8 & 4 & 10 \\
\hline
\end{tabular}

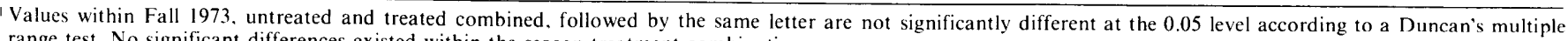
range test. No significant differences existed within the season-treatment combinations.

2 Pellet group data low rate $(0.56 \mathrm{~kg} / \mathrm{ha})$ and high rate $(1.12 \mathrm{~kg} / \mathrm{ha})$ treated areas were combined. 
ently, extra deer also were later attracted from outside onto the pasture, perhaps in response to the hypothesized qualitative improvement in browse on the treated ground. There is no other apparent explanation for the recorded peak in animal numbers, since crown cover was reduced, which should have had a negative effect; screening at deer height was unaffected by treatment; and forbs should have been present equally inside and outside the pasture at that time.

Patterned herbicide treatment of Rio Grande Plain mixed brush in a scheme similar to that used for this study can be expected to cause a substantial proportion of the deer to evacuate the treated pasture as vegetation is acutely affected. However, when forbs recover and succulent woody plant regrowth develops, providing attractive food sources, the deer should return, probably in greater than normal numbers. Thereafter, numbers should return to normal. As long as sprayed woody plants remain upright providing cover screen, strip heribicide treatments seem to have little impact on the deer herd.

\section{Literature Cited}

Beasom, S. L., and C. J. Scifres. 1977. Population reactions of selected game species to aerial herbicide application in South Texas. J. Range Manage. 30:138-142.

Box, T. W., and J. Powell. 1965. Brush management techniques for improved forage values in South Texas. Trans. N. Amer. Wildl. Conf. 30:285-296.

Chamrad, A.D., and T.W. Box. 1968. Food habits of white-tailed deer in South Texas. J. Range Manage. 21:158-164.
Darr, J. W., and D. A. Klebenow. 1975. Deer, brush control, and livestock on the Texas Rolling Plains. J. Range Manage. 28:115-119.

Dasmann, R. T., and R. D. Taber. 1955. A comparison of four deer census methods. California Fish and Game 44:225-228.

Davis, R. B., and R. L. Spicer. 1965. Status of the practice of bush control in the Rio Grande Plain. Texas Parks and Wildl. Bull. No. 46.40 p.

Drawe, D. L. 1968. Mid-summer diet of deer on the Welder Wildlife Refuge. J. Range Manage. 21:164-166.

Everitt, J. H., and D. L. Drawe. 1974. Spring food habits of white-tailed deer in South Texas Plains. J. Range Manage. 27:15-19.

Inglis, J. M. 1964. A history of vegetation on the Rio Grande Plain. Texas Parks and Wildl. Bull. No. 45. 122 pp.

Longhurst, W. M. 1954. The fecal pellet-group deposition rate of domestic sheep. J. Range Manage. 18:418-419.

McMahan, C. A. 1973. Use of Rio Grande Plain brush types by whitetailed deer and analysis of influents. PhD Diss. Dep. Wildl. and Fisheries Sci., Texas A\&M Univ., College Station. 105 pp.

Muller, C. H. 1974. Vegetation and climate of Coahuila, Mexico. Madrono 9 22-57.

Robinetee, W. L., R. B. Ferguson, and J. S. Gashwiler. 1958. Problems involved in the use of pellet group counts. Trans. N. Amer. Wildl. Conf. 23:411-425.

Severinghaus, C. W., and E. K. Cheatum. 1956. Life and Times of the White-tailed Deer of North America. The Stackpole Co., Harrisburg, Pa. 688 p.

Shaw, R. B. 1976. Vegetative responses and cattle activity following patterned herbicide application. M Sci Thesis. Dep. Range Sci., Texas A\&M Univ., College Station. $102 \mathrm{p}$.

Teer, J. G., and N. K. Forrest. 1968. Bionomic and ethical implications of commercial game harvest programs. Trans. N. Amer. Wildl. Conf. 33:192-204.

Whitson, R. E., S. L. Beasom, and C. J. Scifres. 1977. Economic evaluation of cattle and white-tailed deer response to aerial spraying of mixed brush. J. Range Manage. 30:214-217.

Wight, H. M. 1938. Field and laboratory techniques in wildlife management. Univ. of Michigan Press. Ann Arbor. 105 p.

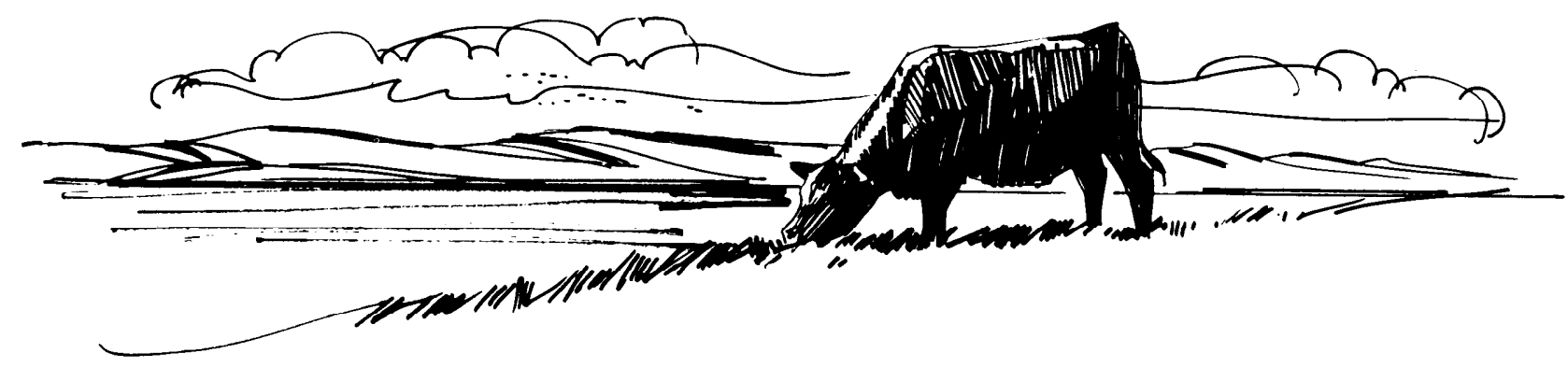

